\title{
Influence of spray drying conditions on the physical properties of dried pulp tomato
}

\author{
Influência das condições de secagem por atomização sobre as \\ propriedades físicas da polpa de tomate desidratada
}

\author{
Alexandre Santos SOUZA ${ }^{1}$, Soraia Vilela BORGES ${ }^{2 *}$, Natália Ferreira MAGALHÃES ${ }^{3}$, \\ Hevandro Vaz RICARDO ${ }^{3}$, Marney Pascoli CEREDA ${ }^{4}$, Erica Regina DAIUTO ${ }^{5}$
}

\begin{abstract}
A complet factorial experimental design was applied to determinate the influence of the variable inlet air temperature, feed flow rate, and atomizer speed on the physical properties of the tomato pulp powder. Results showed that these variables had a significant positive effect on the moisture content, apparent density, and particle size and no significant effects on the porosity and true density. The best spray drying conditions to produce lower moisture content and higher apparent density tomato powder were inlet air temperature of $200{ }^{\circ} \mathrm{C}$, feed flow rate of $276 \mathrm{~g} / \mathrm{min}$, and atomizer speed of $30000 \mathrm{rpm}$.

Keywords: vegetables; drying; food powder properties.
\end{abstract}

\section{Resumo}

Um planejamento fatorial completo foi aplicado para determinar a influência das variáveis: temperatura de entrada do ar, vazão de alimentação e velocidade do atomizador sobre as propriedades físicas da polpa de tomate em pó. Resultados mostraram que estas variáveis tiveram um efeito positivo significativo sobre o conteúdo de umidade, densidade aparente e tamanho da partícula e não significativo sobre a porosidade e densidade verdadeira. As melhores condições de secagem por atomização para produção de tomate em pó, menor conteúdo de umidade e maior densidade aparente foram: temperatura do ar de entrada: $200{ }^{\circ} \mathrm{C}$; vazão da alimentação: $276 \mathrm{~g} /$ min; e velocidade do atomizador: 30000 rpm.

Palavras- chave: vegetais; secagem; propriedades de alimentos em pó.

\section{Introduction}

The vegetables have an important role in our diet for being rich in nutrients, especially tomato, and rich in lycopene, an antioxidant substance (ABUSHITA; DAOOD; BIACS, 2000; ANGUELOVA; WARTHESEN, 2000). The Brazilian production in 2002 was about 1.28 millions of tons in an area of 12.25 thousand hectares (EMBRAPA, 2003). However, high contents of water can limit the conservation of these products, but spray drying is one of the methods used in the formation of dried foodstuffs.

Besides, the powder product formed can be used as dry ingredient in dehydrated soups, enrich different nutritious formulas, and contribute to color and flavor (Al- ASHEH et al., 2003).

The quality of the powder foods is based on a variety of properties that depend on specific application. In general, the final moisture content, solubility, rheological properties, and density are of primary importance (RÉ, 1998).

The drying of the mashed tomato fruit is very difficult due to its high sugar concentration and other soluble solids which are responsible for the stickiness of the particles to the dryer walls. However, many possible solutions have been presented to solve this problem such as changing the dimension of the dryer and add polymers which modifies some properties of the products in a way that it increases the temperature in which its particles stick to the dryer walls lessening the problem (BHANDARI; DATTA; HOWES, 1997; BORGES et al., 2002; CANO-CHAUCA et al., 2005; MARA-RIGHETTO; NETTO, 2005; ROUSTAPOUR; HOSSEINALIPOUR; GHOBADIAN, 2006). Other factors that contribute to the manufacturing of high quality powder tomato are raw material and its pre-treatment, the powder processing, the proper processing machine, and the operation condition of the dryer (MASTERS, 1991; MILLER; LUCAE, 1999).

The physical properties of the food related to ease the reconstitution include moisture content, apparent density, true density and respective particle porosity, particle size, and its distribution. These properties are influenced by the nature of the feed (solid content, viscosity, and temperature), type of spray

\footnotetext{
Recebido para publicação em 6/9/2007

Aceito para publicação em 14/1/2008 (002830)

${ }_{1}$ Escola Agrotécnica Federal de Salinas - EAFSalinas, Salinas - MG, E-mail:eng13ale@yahoo.com.br

2 Departamento de Ciência dos Alimentos, Universidade Federal de Lavras - UFLA, Campus Universitário, CEP 37200-000, Lavras - MG, Brasil, E-mail: sborges@ufla.br

${ }^{3}$ Departmento de Tecnlogia de Alimentos, Universidade Federal do Rio de Janeiro - UFRJ, Rio de Janeiro - RJ, E-mails: nataliavix@gmail.com; hevandrovaz@yahoo.com.br

4 Universidade Católica Dom Bosco, Campo Grande-MS, Brasil, E-mail: cereda@ucdb.br

${ }^{5}$ Raízes-ONG, E-mail: daiuto@raizes.org.br

${ }^{*}$ A quem a correspondência deve ser enviada
} 
dryer, operational speed atomization or pressure nozzle, and air inlet and outlet temperatures (MASTERS, 1991; RÉ, 1998; NATH; SAPTHY, 1998).

Higher atomizer speeds decrease particle size (MASTERS, 1991; CHEGINI; GHOBADIAN, 2005), and air incorporation in the feed results in porous products of low apparent density making re-hydration more difficult (WALTON; MUMFORD, 1999).

The objective of this research was to verify the effects of spray drying conditions (atomization speed, inlet air temperature, and the feed flow rate) on tomato powder moisture content, apparent density, true density, porosity, and particle size.

\section{Materials and methods}

Tomato pulp (brand Colonial, Itacarambi, MG, Brasil) was blended with $10 \mathrm{DE}$ (dextrose equivalent) malt dextrin (10\% dry matter, w/w) and SiO2 (1\% dry matter, w/w) and spray dried in a pilot scale spray dryer (home made/DTA, UFRRJ, Brazil). The dimensions of the drying chamber were $2.5 \mathrm{~m}$ in diameter and $1.40 \mathrm{~m}$ cylindrical height with a conical base. All internal surfaces that contact the product are made of stainless steel AISI 316. It is equipped with a control panel (control of the atomizer speed, blower velocity, and air inlet temperatures), a rotary atomizer and gas burner. The feed was pulverized by a rotary atomizer and the air entrance, co-current flow, was supplied by a blower. The constant operational conditions were outlet air temperature of $90{ }^{\circ} \mathrm{C}$ and blower velocity of $30000 \mathrm{rpm}$. The variables (real, codified) atomization speed (AS, X3), feed flow rate $(\mathrm{Q}, \mathrm{X} 2)$, and inlet temperature $(\mathrm{T}, \mathrm{X} 1)$ were studied according to a complete 23 factorial design with three repetitions at the central point (Table 1). The codified variables (Xn) are obtained by following relationship: $\mathrm{Xn}=(\mathrm{RV}-\mathrm{RV}(\mathrm{CP})) / \Delta \mathrm{RV}$, where $\mathrm{RV}$ is real value for the variable, $R V(C P)$ is real value for the variable at the central point and $\triangle \mathrm{RV}$ is the difference between higher and minor real values.

The powdered samples were filled in low-density polyethylene pouches and stored at $10{ }^{\circ} \mathrm{C}$ until analyzed. The results were submitted to variance analysis and effect estimative according to Barros Neto; Scarmínio; Bruns, 1995, using the statistical software STATISTICA 5.0 (STATSOFT, Tulsa, OK, USA).

Table 1. Experimental conditions for the factorial design.

\begin{tabular}{ccccccc}
\hline Assay & $\mathrm{X} 1$ & $\begin{array}{c}\mathrm{T} \\
\left({ }^{\circ} \mathrm{C}\right)\end{array}$ & $\mathrm{X} 2$ & $\begin{array}{c}\mathrm{Q} \\
(\mathrm{g} / \mathrm{min})\end{array}$ & $\mathrm{X} 3$ & $\begin{array}{c}\mathrm{AS} \\
(\mathrm{rpm})\end{array}$ \\
\hline 1 & +1 & 220 & +1 & 276 & -1 & 25000 \\
2 & -1 & 200 & +1 & 276 & -1 & 25000 \\
3 & +1 & 220 & -1 & 127 & -1 & 25000 \\
4 & -1 & 200 & -1 & 127 & -1 & 25000 \\
5 & +1 & 220 & +1 & 276 & +1 & 35000 \\
6 & -1 & 200 & +1 & 276 & +1 & 35000 \\
7 & +1 & 220 & -1 & 127 & +1 & 35000 \\
8 & -1 & 200 & -1 & 127 & +1 & 35000 \\
9 & 0 & 210 & 0 & 201 & 0 & 30000 \\
10 & 0 & 210 & 0 & 201 & 0 & 30000 \\
11 & 0 & 210 & 0 & 201 & 0 & 30000 \\
\hline
\end{tabular}

The following analyses were carried out on tomato powders: moisture content (vacuum oven at $70{ }^{\circ} \mathrm{C}$ to a constant weight, Instituto Adolfo Lutz-IAL, 1985); the apparent density (AD) of the powders, determined by measuring the volume of a determined weight of powder in a glass cylinder; the true bulk density (TD), determined by a picnometer, using toluene as the immiscible liquid, and porosity (1- TD/AD) according to LEWIS (1993).

The particle size was measured by microscopy (AXIOSKOPIIZeiss) using the software KS 300.200, and the Sauter's diameter (the diameter of a sphere that has the volume/surface area ratio as a particle of interest) was calculated.

\section{Results and discussion}

Table 2 presents the estimates of the effects on the physical properties analyzed.

Concerning moisture content, the obtained results showed that the atomization speed presented little effect (level of probability of 5\%) on the tomato powder humidity. These relations can be expressed by Equation 1 considering X3 $=0$, which fitted the linear model well $(\mathrm{R} 2=0.96)$.

$\mathrm{MC}=5.69-0.31 * \mathrm{X} 1-0.14 * \mathrm{X} 2-0.52 * \mathrm{X} 1 * \mathrm{X} 2$

Figure 1 represents the model more adequately.

Analyzing Figure 1, it can be observed that the increase in temperature and decrease in feed flow rate reduce the moisture content of the product. These results are due to higher drying rate and decreased amount of water introduced to the drier (MASTERS, 1991; PEREZ-MUNOZ; FLORES, 1997). Similar results were obtained by Al-Asheh et al. (2003), Goula, Adamapoulos (2005) for tomato pulp powder; by Abadio et al. (2004) and Chegini; Ghobadian (2005) for pineapple and orange juice powder, respectively, and by Hong, Choi (2007) for proteinbound-polysaccharide powder.

With relation to the apparent density, the results showed that the inlet air drying temperature, atomization speed, feed flow rate, and the interaction among these three variables presented significant effect. These relations can be expressed by Equation 2 considering X3 = $0(\mathrm{R} 2=0.96)$.

$\mathrm{AD}=0.60-0.034 * \mathrm{X} 1+0.04 * \mathrm{X} 2-0.01 * \mathrm{X} 1 * \mathrm{X} 2$

Table 2. Estimates of the effect on physical properties.

\begin{tabular}{lcccrc}
\hline \multicolumn{1}{c}{ Factor } & $\begin{array}{c}\mathrm{MC} \\
\mathrm{g} / 100 \mathrm{~g}\end{array}$ & $\begin{array}{c}\mathrm{AD} \\
(\mathrm{g} / \mathrm{mL})\end{array}$ & $\begin{array}{c}\mathrm{TD} \\
(\mathrm{g} / \mathrm{mL})\end{array}$ & $\varepsilon$ & $\begin{array}{c}\mathrm{PS} \\
(\mu \mathrm{m})\end{array}$ \\
\hline Mean/Int. & 5.70 & 0.60 & 1.18 & 0.53 & 52.00 \\
$\mathrm{X} 1$ & -0.06 & 0.07 & -0.10 & -0.01 & -3.00 \\
$\mathrm{X} 2$ & -0.28 & $0.08^{*}$ & 0.09 & 0.00 & $5.00^{*}$ \\
$\mathrm{X} 3$ & -0.02 & $-0.08^{*}$ & -0.03 & -0.01 & $-13.00^{*}$ \\
$\mathrm{X} 1{ }^{*} \mathrm{X} 2$ & $-1.04^{*}$ & -0.03 & 0.04 & -0.01 & 1.00 \\
$\mathrm{X} 1{ }^{*} \mathrm{X} 3$ & 0.24 & -0.02 & -0.05 & -0.00 & -4.00 \\
$\mathrm{X} 2{ }^{*} \mathrm{X} 3$ & 0.37 & -0.04 & -0.12 & -0.00 & 1.00 \\
$\mathrm{X} 1{ }^{*} \mathrm{X} 2{ }^{*} \mathrm{X} 3$ & $0.91^{*}$ & 0.00 & -0.00 & 0.01 & -0.00 \\
\hline
\end{tabular}

${ }^{*}$ significative at $\mathrm{p}<0,05, \mathrm{MC}$ : moisture content, $\mathrm{AD}$ : apparent density, TD: true density, $\varepsilon:$ porosity, PS: particle size (Sauter's diameter). 
Figure 2 represents the model more adequately.

It can be observed that the apparent density has decreased with the increase of the inlet air temperature according to the results previously observed by Walton (2000), Al-Asheh et al. (2003), Chegini, Ghobadian (2005). The porous structures are favored by high drying rate promoted by the use of high temperatures due to the expansion of evaporation of water vapour leaving the empty spaces occupied by the air (NATH; SATPATHY, 1998; WALTON, 2000).

Al- Asheh et al. (2003) found density values in the order of 0.54 a $0.78 \mathrm{~g} / \mathrm{ml}$; similar results were found in this work. Goula, Adamapoulos (2005) using dehumidified air and compressed air flow rate obtained smaller values $(0.50-0.37)$ for this same product.

The apparent density increased with the increase of the feed flow rate and with the decrease of the atomization speed. Similar trends were found by Al-Asheh et al. (2003) and Chegini, Ghobadian (2005) since higher feed flow rate lead to a minor degree of moisture removal, and this moisture content, due to higher density compared to the dry solid, contributed to the increase of this property. According to Bhandari; Balachandran (1998), at lower atomization speed the particles become larger and denser. For fruits dehydrated by this process, the apparent density was not affected by the atomization speed, (FRANCISCONI et al., 2003, ABADIO et al., 2004) with values of $0.46 \mathrm{~g} / \mathrm{ml}$ for passion-fruit powder and $0.59 \mathrm{~g} / \mathrm{ml}$ for pineapple juice powder.

The values of true density were in the range of 1.07 to 1.31 g.mL $\mathrm{mL}^{-1}$ and the variables under study did not have a significant influence over them. For dehydrated fruits (FRANCISCONI et al., 2003, ABADIO et al., 2004), this property was reduced with the increase of the atomization speed, due to previously explained reasons, and its values were in the range of 1.52 to $1.76 \mathrm{~g} / \mathrm{ml}$, respectively, for pineapple juice and passion-fruit juice powder, values slightly higher than the ones of powder tomato.

The porosity values were in the range of 0.50 to 0.59 and were not affected by the conditions under study and by the factors that influenced this property either (the same conditions that affected the true apparent density). Borges et al. (2002) found a porosity value of 0.86 for the dehydrated passion-fruit juice powder using aspersion nozzles.

The diameter of the particles of the 11 experiments was distributed in a single modal way, which demonstrates that there was homogeneous production during the drying.

The results demonstrate that the atomizer speed and the feed flow rate showed significant effect, to the level of 5\% of probability, on the particle size of the tomato powder.

These relations can be expressed by Equation 3, considering $\mathrm{X} 1=0,(\mathrm{R} 2=0.97)$. Figure 3 represents the model more adequately.

Particle size $=52.25+2.73 * \mathrm{X} 2-6.36 * \mathrm{X} 3+0.74 * \mathrm{X} 2 * \mathrm{X} 3$

The particle size decreases with the increase of the atomization speed due to higher atomizer wheels speeds and a decrease of droplet and therefore particle size (MASTERS, 1991). The increase in the feed flow rate causes an increase in the particle size and a similar tendency was found by Al-Asheh et al. (2003) dehydrating the same product and by Chegini, Ghobadian (2005) for orange juice powder. Al-Asheh et al. (2003) attributed this result to the high probability of collision and following fusion of small drops, and the particles size for this author was an average of $9,11 \mu \mathrm{m}$, smaller than the values found in this work. This is due

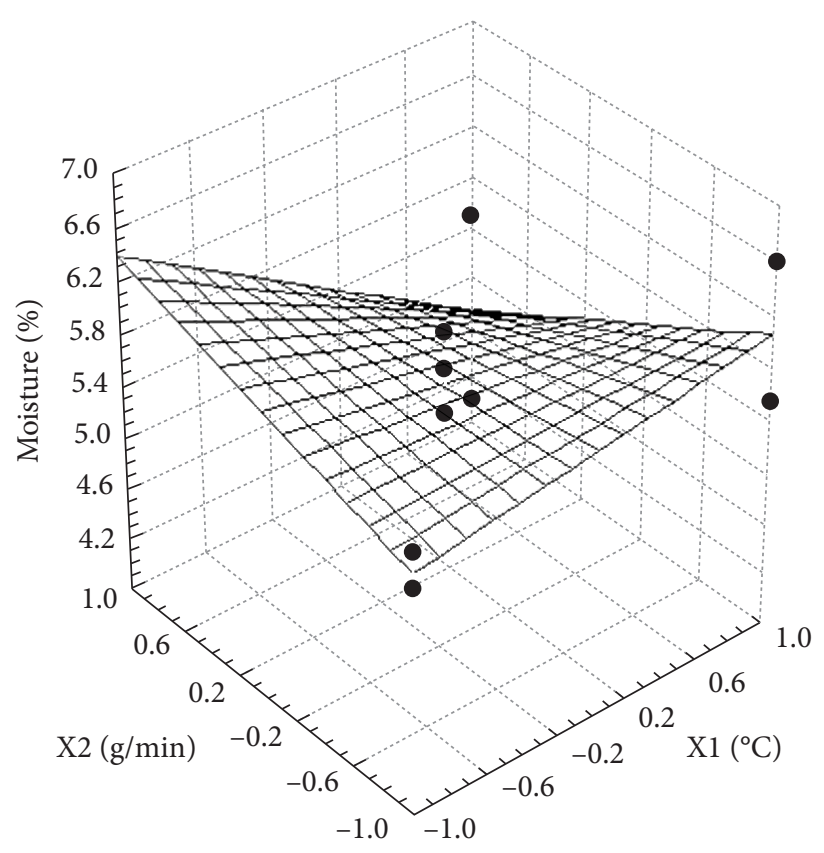

Figure 1. Moisture content of powder at X3 $=0$.

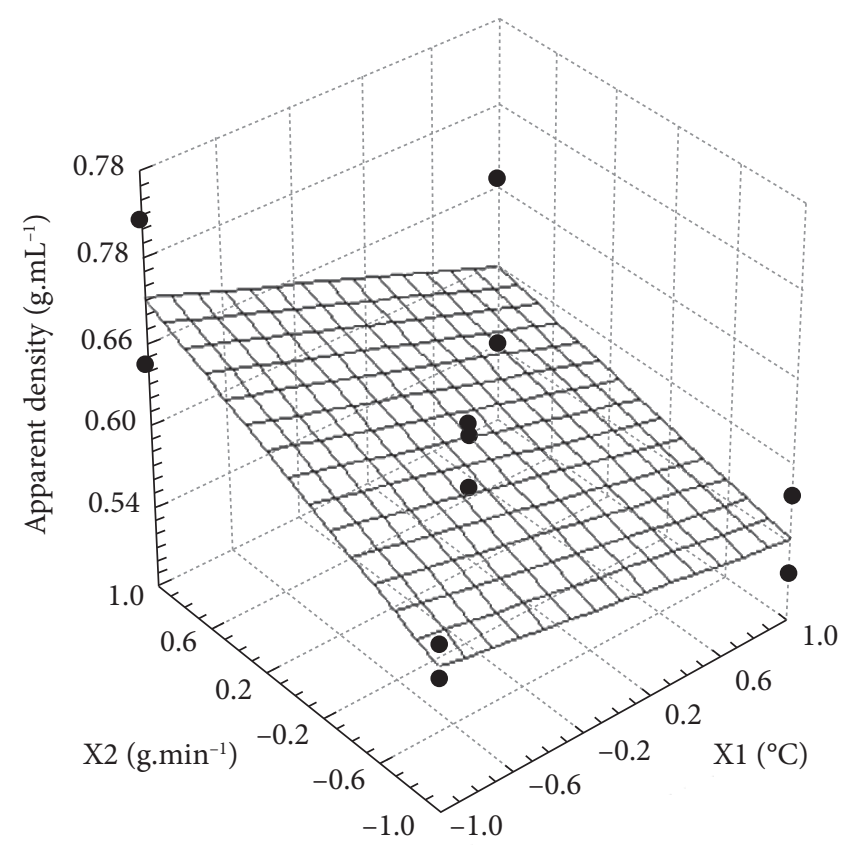

Figure 2. Apparent bulk density at X3 $=0$. 


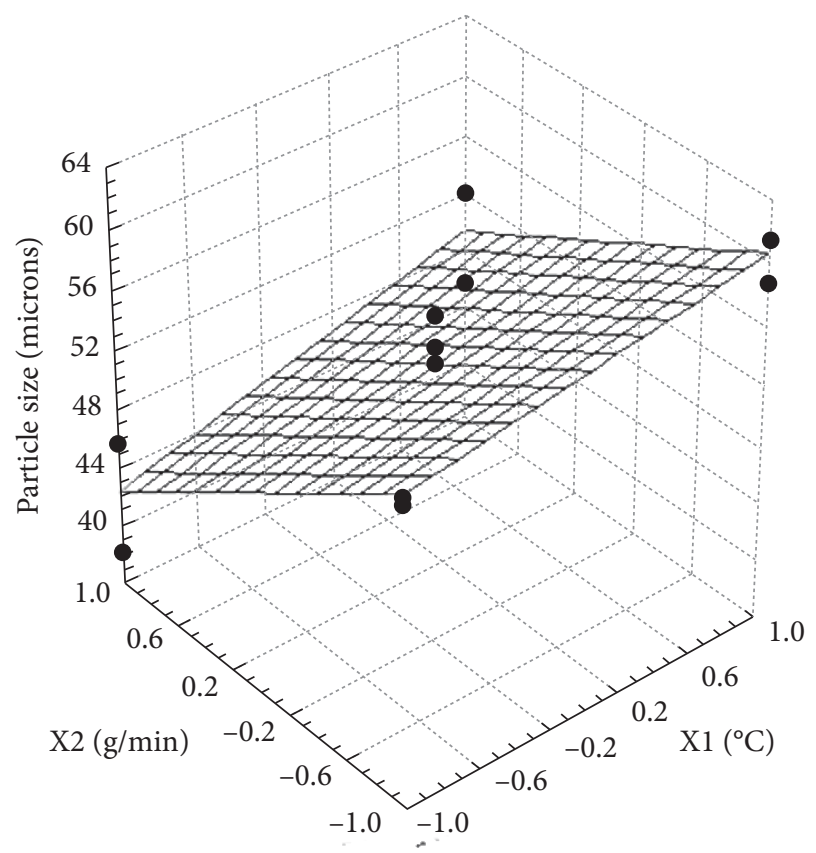

Figure 3. Particle size for the tomato powder obtained at $\mathrm{X} 1=0$.

to the different drying method used by the author, especially the concentration of solution solids which was lower than the one used in this work (maximum 9\%) and that affects the particles size as verified in the research of the referred author.

\section{Conclusion}

The results indicate that the porosity and true density were not influenced by the variables studied. The best spray drying conditions to produce lower moisture content and higher apparent density tomato powder were inlet air temperature of $200^{\circ} \mathrm{C}$, feed flow rate of $276 \mathrm{~g} / \mathrm{min}$, and atomizer speed of $30000 \mathrm{rpm}$.

\section{Acknowledgment}

The authors are grateful for the financial support provided by FAPERJ (The State of Rio de Janeiro Research Foundation), Karambi Alimentos, and to Corn Brazil and Arinos Química that supplied raw materials and additives.

\section{References}

ABADIO, F. D. B. et al. Physical properties of powdered pineapple (Ananas comosus) juice: effect of malt dextrin concentration and atomization speed. Journal of Food Engineering, v. 64, n. 3 , p. 285-287, 2004.

ABUSHITA, A. A.; DAOOD, H. G.; BIACS P. A. Change in carotenoids and antioxidant vitamins in tomato as a function of varietal and technological factors. Journal Agricutural and Food Chemistry, v. 48 , n. 6 , p. $2075-2081,2000$.

$\mathrm{Al}-\mathrm{ASHEH}$, S. et al. The use of experimental factorial design for analysing the effect of spray dryer operating variables on the production of tomato powder. Transaction Institute Chemical Engineering, v. 81, Part C, p. 81-88, 2003.
ANGUELOVA, T.; WARTHESEN, J. Lycopene stability in tomato powders. Food Chemical Toxicolology, v. 65, n. 1, p. 67-70, 2000.

BARROS NETO, B.; SCARMÍNIO, I. S.; BRUNS, R. E. Planejamento e otimização de experimentos. Campinas: UNICAMP, 1995.

BHANDARI, B. R.; DATTA, N.; HOWES, T. Problems associated with spray dry of sugar-rich foods. Drying Technology, v. 15, n. 2, p. 671-685, 1997.

BHANDARI, U.; BALACHANDRAN, R. Influence of drying conditions on the particle size and bulk density of spray dried ice cream mix. Indian Journa Dairy Science, v. 41, n. 1, p. 132-133, 1998.

BORGES, S. V. et al. Jugo de frutas tropicales deshidratados por spray drying. Alimentaria, v. 334, p. 125-130, 2002.

CANO-CHAUCA, M. et al. Effect of the carriers on the microstructure of mango powder obtained by spray drying and its functional characterization. Innovatives Food Science \& Emerging Technologies, v. 4, n. 6, p. 420-428, 2005.

CHEGINI, G. R.; GHOBADIAN, B. Effect of spray drying conditions on physical properties of orange juice powder. Drying Technology, v. 23, n. 3, p. 657-668, 2005.

FRANCISCONI, A. D. et al. Propiedades físicas del jugo de maracuyá en polvo: efecto de la velocidad de atomización y concentración de maltodextrina. Alimentaria, v. 346, p. 97-100, 2003.

GOULA, A. M.; ADAMAPOULOS, K. G. Spray drying of tomato pulp in dehumidified air: II. The effect on powder properties. Journal of Food Engineering, v. 66, n. 1, p. 35-42, 2005.

HONG, J. H.; CHOI, Y. H. Physico-chemical properties of proteinbound-polysaccharide from Agaricus blazei Murill by ultrafiltration and spray drying process. International Journal of Food Science and Technology, v. 42, n. 1, p. 1-8, 2007.

INSTITUTO ADOLFO LUTZ. Normas analíticas: métodos físicos y químicos para análise de alimentos. São Paulo, 1985.

LEWIS, M. J. Propriedades físicas de los alimentos y de los sistemas de procesado. Zaragoza: Acribia, 1993.

MARA-RIGHETTO, A.; NETTO, F. M. Effect of encapsulating materials on water sorption, glass transition and stability of juice from immature acerola. International Journal of Food Properties, v. 8, n. 2, p. 337-346, 2005.

MASTERS, K. Spray drying handbook. London: Longman Scientific and Technical, 1991.

MILLER, E.; LUCAE, T. Real tomato powder. Food Marketing Technology, v. 13, n. 1, p. 18-20, 1999.

NATH, S.; SAPATHY, G. R. A sistematic approach for investigation of spray drying process. Drying Technology, v. 16, n. 6, p. 1173-1193, 1998.

PEREZ-MUNOZ, F.; FLORES, R. A. Characterization of a spray drying system for soy milk. Drying Technology, v. 15, n. 3-4, p. 1023-1043, 1997.

RÉ, M. I. Microencapsulation by spray drying. Drying Technology, v. 16, n. 6, p. 1195-1136, 1998.

ROUSTAPOUR, O. R.; HOSSEINALIPOUR, M.; GHOBADIAN, B. An experimental investigation of lime juice drying in pilot plant spray drying. Drying Technology, v. 24, n. 2, p. 181-188, 2006.

WALTON, D. E. The morphology of spray dried particles: a qualitative view. Drying Technology, v. 18, n. 9, p. 1943-1986, 2000.

WALTON, D. E.; MUMFORD, C. J. The morphology of spray-dried particles-the effect of process variables upon the morphology of spraydried particles. Transactions Institute of Chemical Engineering, v. 77, Part A, p. 442-460, 1999. 